〔澱粉科学 (J. Jap. Soc. Starch Sci.) 第 25 巻 第 2 号 $\quad$ p.83 88 (1978))

\title{
アミラーゼ産生腫瘍の形態学的, 生化学的検討
}

\author{
竹内利行* ・亀谷 徹** \\ Morphological and Biochemical Studies on Amylase-Producing Tumors \\ Toshiyuki TAKEUCHI* and Toru KAMEYA** \\ *Biochemistry Division, **Pathology Division, \\ National Cancer Center Research Institute
}

ある種の腫瘍では, その腫瘍の原発組織が産生してい ないホルモンや酵素を産生することがある1,2)。医学分 野では本来の産生臟器由来のホルモンや酵素を正所性, 産生されるはずのない組織の腫瘍化によって由来するホ ルモンや酵素を異所性と形容している。この異所性ホル モンや異所性酵素は肺癌にしばしば見られる。異所性ホ ルモンの例としては adrenocorticotropic hormone (AC$\mathrm{TH})^{3)}, \beta$-melanocyte stimulating hormone $(\beta \mathrm{MSH})^{4)}$, calcitonin $^{5)}$, parathyroid hormone $(\mathrm{PTH})^{6}$, human chorionic gonadotropin $(\mathrm{HCG})^{7)}$ 等のペプチドホルモン が知られ, 異所性酵素の例としてはアルカリフォスファ ターゼ8やアミラーゼダが知られている.

われわれはアミラーゼ産生肺癌 2 症例, 卵巣癌 1 症例 を経験し, 腫瘍の組織学的検討と産生アミラーゼの生化 学的検討を行った ${ }^{10)}$. 症例 1 (48歳男性) は, 1974年秋 頸部リンパ腺腫脹を主訴として某病院を受診, 肺癌の診 断を受けた. 入院後胸部陰影増大に伴って高アミラーゼ 血症を呈した. 1975年 2 月死亡. 検体は剖検時のもので ある. 病理組織診断は気管支肺胞上皮性腺癌である（図 1, a). 症例 2 (46歳女性) は，1965年に胸部陰影を指摘 されたが経過は緩慢であった. 1974年から高アミラーゼ 血症を呈するようになり，1975年春確定診断のためにバ イオプシーを行った．その結果，肺腫瘍であることが判 明した，検体はバイオプシー時のものである，病理組織 診断は未確定であるが，気管支腺由来の低分化型腺癌を 思わせるものである（図 $2 \mathrm{a}$ ). 症例 3 (51歳女性) は, 1975年右下腹部痛のため某病院を受診し, 巨大卵巣腫瘍 の診断を受けた。 入院時, 高アミラーゼ血症を発見され

* 国立がんセンター研究所生化学部

** 同第 3 病理部 (104 東京都中央区築地 5-1-1)
た. 1976年 5 月死亡. 検体は剖検時のものである. 病理 組織診断は, 漿液性乳頭状のう胞腺癌である (図 $3 \mathrm{a}$ ).

上記 3 症例とも血清と腫瘍中のアミラーゼ活性は正常 血清および正常肺組織中の活性の数十倍の高值を示した. しかし，アミラーボ産生臓器である唾液腺や膵臓のアミ ラーゼ值と比較すると 100 分の 1 以下であった(図 4). したがってアミラーゼ産生腫湯といっても, その産生能 は唾液腺や膵臓と比較するとはるかに低いものである. 組織所見も, 3 症例とも唾液腺や膵臓とは類似性がない (図 1a,2a,3a).

アミラーゼの腫瘍内局在は抗ヒト唾液腺アミラーゼ抗 体を用いた免疫螢光抗体法て確かめた。 3 症例ともアミ ラーゼは腫瘍蜂巣中に局在し, 正常組織部分には存在し なかった(図 $1 \mathrm{~b}, 2 \mathrm{~b}, 3 \mathrm{~b})$. なお，唾液腺アミラーゼと膵 臓アミラーゼは抗原性を同じくするために，抗体を用い ては後述する唾液腺型アミラーゼと膵蔵型アミラーゼの 識別はできなかった11).

アミラーゼは, 唾液腺と膵臓の外分泌細胞中の分泌顆 粒中に存在している12). それでは， 3 症例の腫瘍細胞中 には分泌顆粒は見出せるであろらか. 症例 1 では, 残念 ながら電子顕微鏡用の標本を得ることがでさなかった。

しかしGomi らは, 症例 1 と同じ気管支肺胞上皮性腺癌 の組織型を示すアミラーゼ産生腫瘍で細胞中に豊富な分 泌顆粒を観察している ${ }^{13)}$. 症例 2 では, 分泌顆粒は少し ではあるが認められる(図 5 ). 症例 3 では, 分泌顆粒は 全く認められなかった(図6)。したがって, 腫瘍のアミ ラーゼ産生能と顆粒形成能とは必ずしも並行しないと考 えられる.

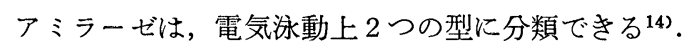
すなわち, 睡液腺アミラーゼと同一の泳動位置, および 


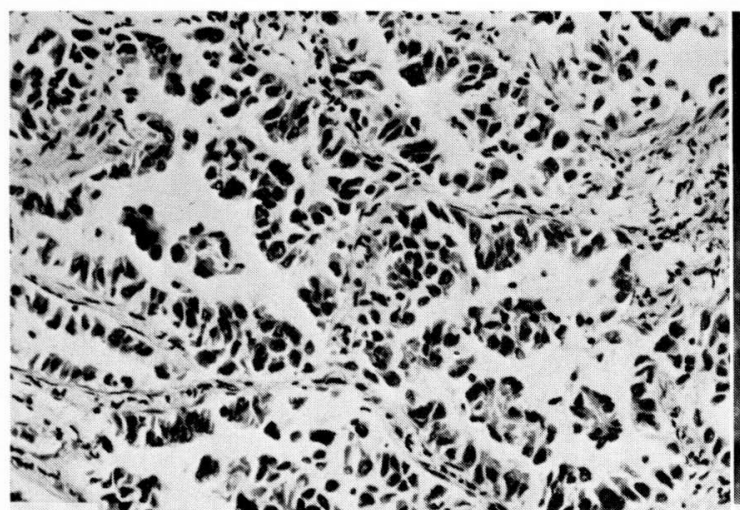
1 a

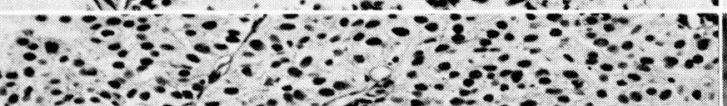

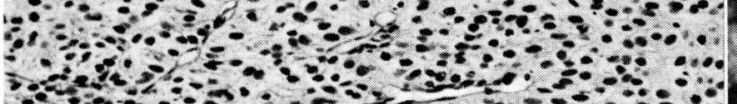

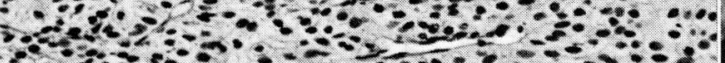
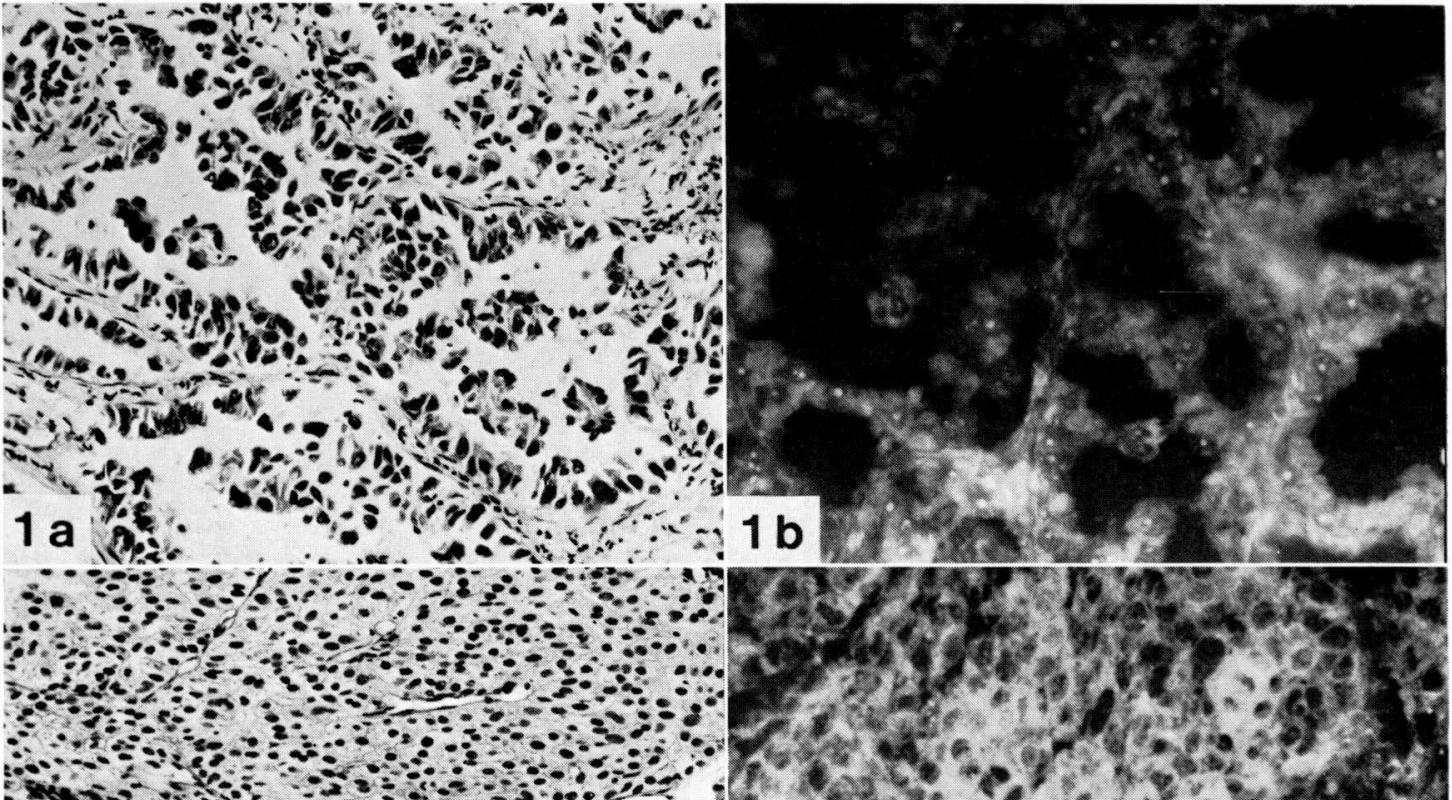

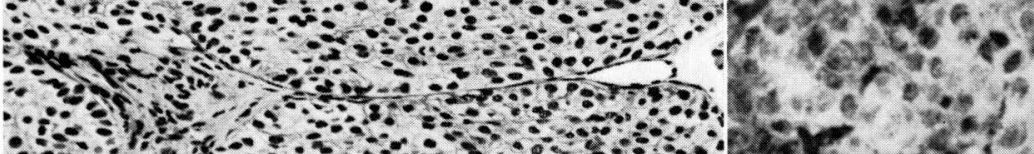

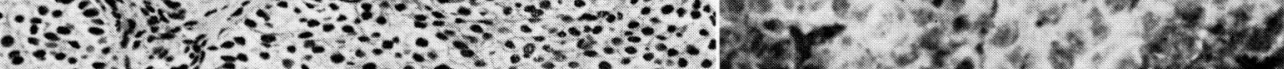

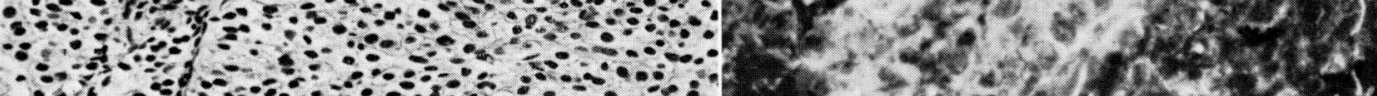

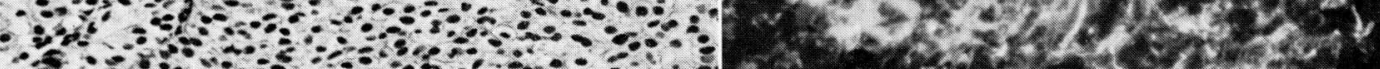

3.

2 a

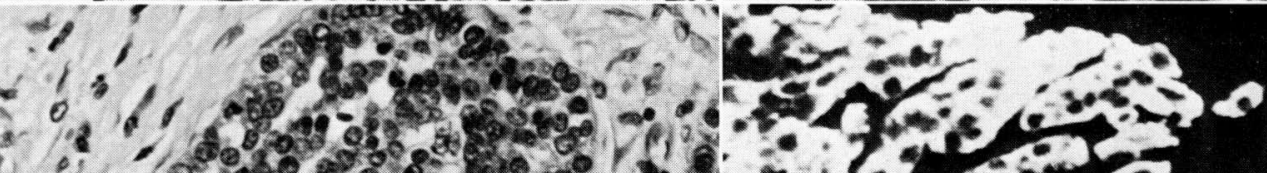

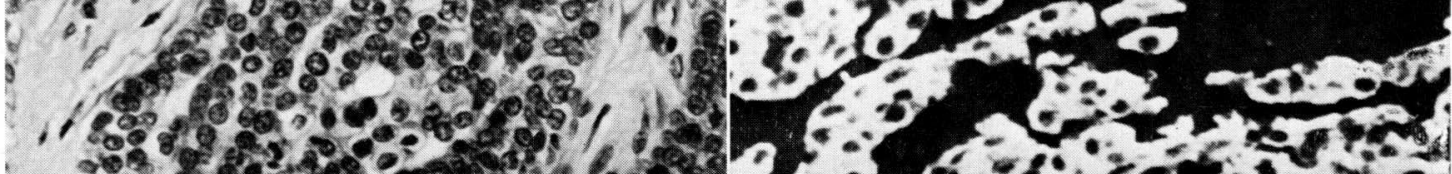

$1 / 8 \%$

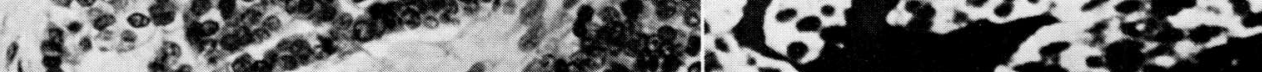

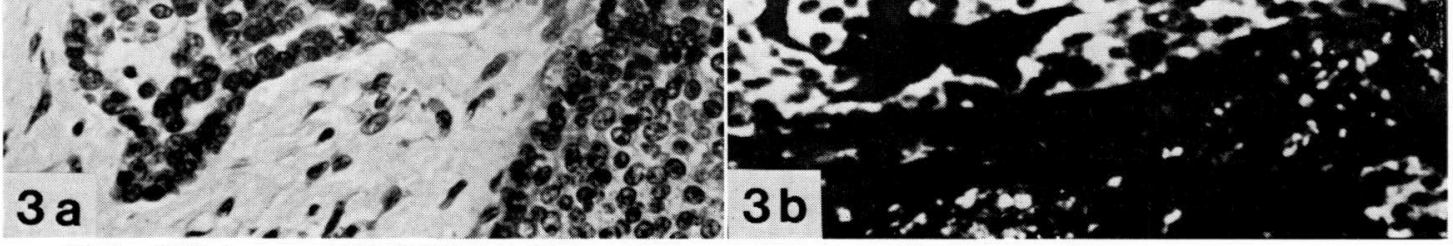

図 1. 症例 1 a : 気管支肺胞上皮癌（へマトキシリンーエオジン染色 $\times 680)$,

図 2. 症例 2 a : 低分化型気管支腺由来と考光られる肺腫瘍（ヘマトキシリンーエオジン染色 $\times 340$ ),

図 3. 症例 $3 \quad \mathrm{a}$ : 卵䉓原発漿液性乳頭状の5胞腺癌, $\mathrm{b}$ : 螢光抗体法によるアミラーゼの局在

膵蔵アミラーゼと同一の泳動位置を示す 2 つの型である。

等電点 $(\mathrm{p} I)$ でいらと, 唾液腺アミラーゼは $\mathrm{p} I=6.4$ で

あり, 膵蔵アミラーゼは $\mathrm{p} I=6.9$ である15). 3 症例の
血清および腫瘍組織ホモジェネート $105,000 \mathrm{~g}$ 上清中の

アミラーゼを等電点分画した. 症例 1,2 では, アミラー

ゼは $\mathrm{p} I=6.4$ を主成分とし，より低い $\mathrm{p} I$ を有する小 
Control serum

Serum (Case 1)

Serum (Case 2)

Serum (Case 3)

Control lung

Lung tumor (Case 1)

Lung tumor (Case 2)

Ovarian tumor (Case 3)

Transplanted tumor

(Case 3)

Lung tumor without hyperamylasemia

Parotid gland

Pancreas

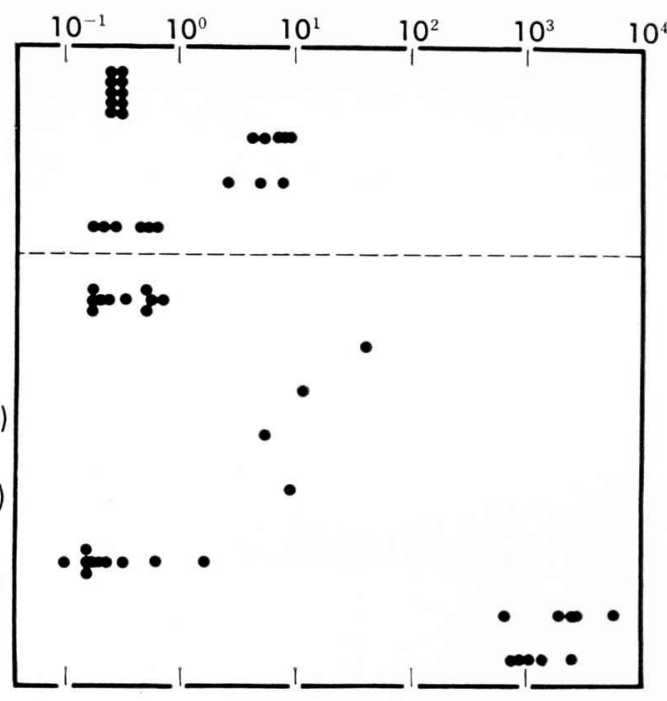

成 4. 症例 $1,2,3$ の血清および腫瘍中アミラーゼ活性と各種臓器中アミラーゼ值の比較 単位は international units $/ \mathrm{ml}$ or $\mathrm{g}$ 湿重量で表わし, 刘数で表示してある。

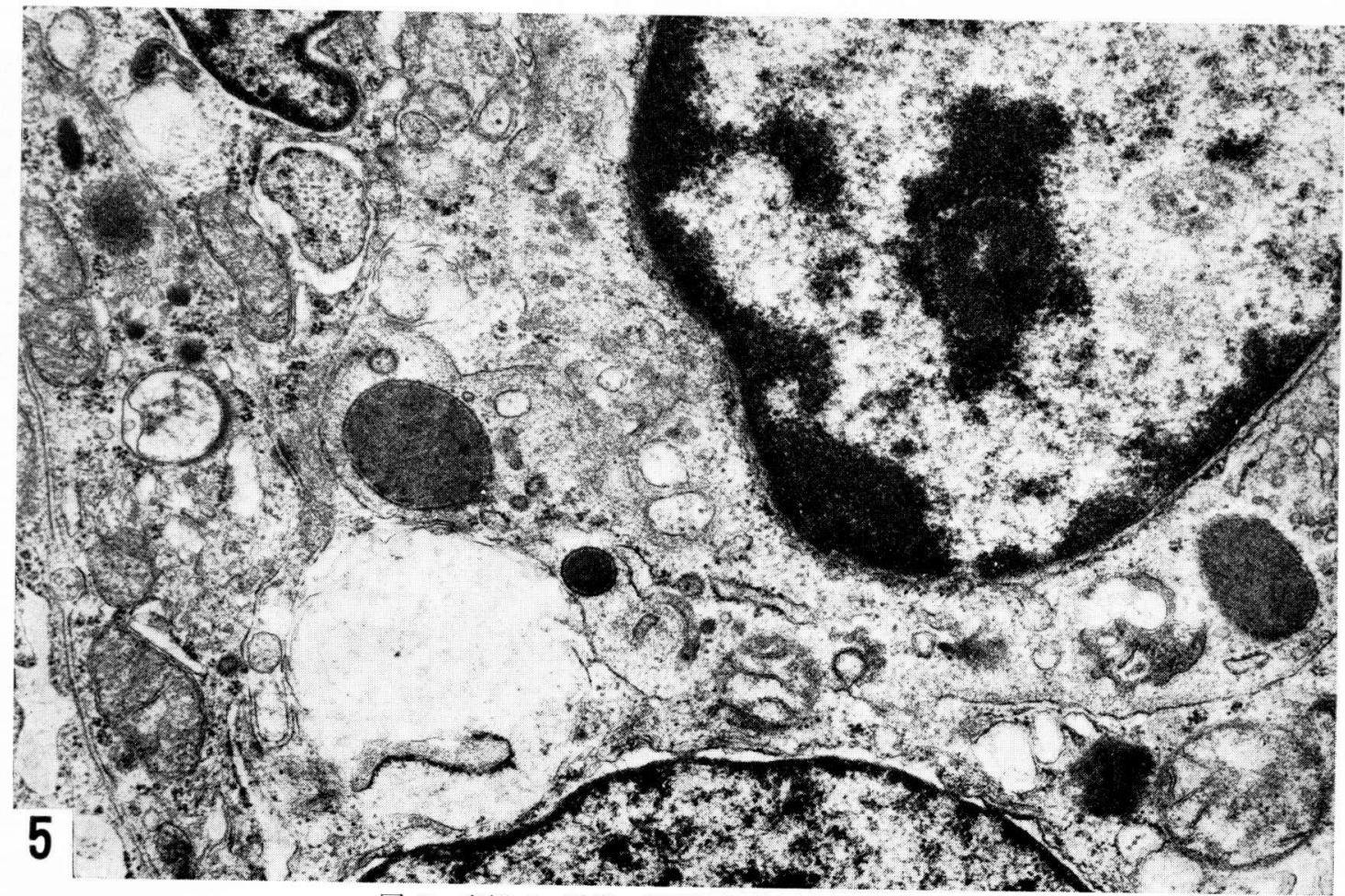

図 5. 症例 2 腫瘍の電子顕微鏡写真 $(\times 20,000)$

成分を数本伴らパターンを示した（図７）。主成分の $\mathrm{p} I$ $=6.4$ は, 唾液腺アミラーゼのそれ子一致する.症例 $3 て$ は血清アミラーゼは $\mathrm{p} I=5.1,[5.3,5.4,5.9,6.4 ” の$ 各 成分に広く分れたが, 腫瘍組織ホモジェネート105,000g
上清中のアミラーゼは $\mathrm{p} I=5.9$ を主成分とし， $\mathrm{p} I=5.5$, 6.2 の小成分を伴らパターンを示した。この腫瘍は, 又 ードマウスへの移植が成功した，移植腫瘍のホモジェネ 一ト $105,000 \mathrm{~g}^{\top}$ 上清中のアミラーゼは, 原腫瘍中アミラ 


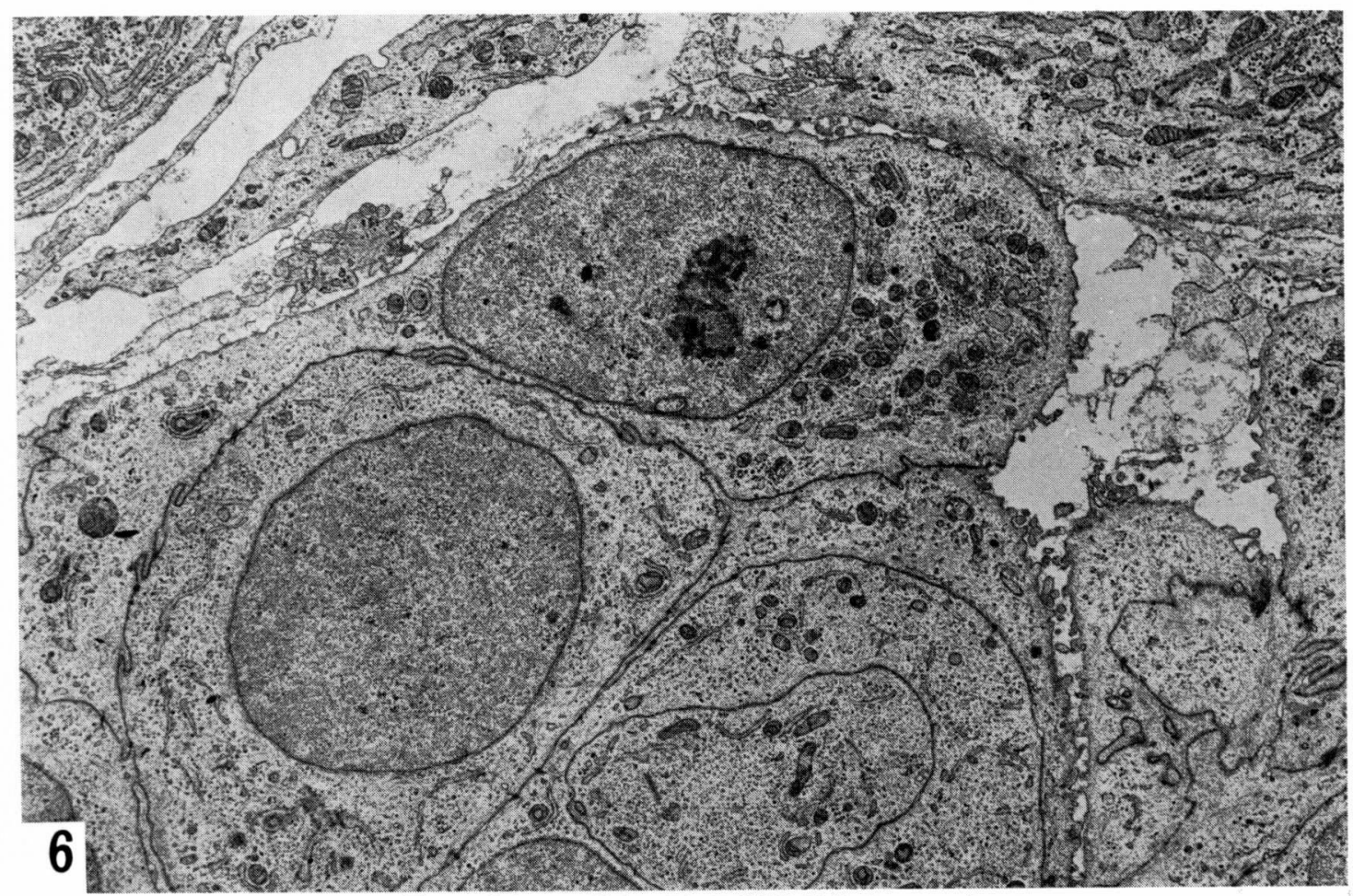

図 6. 症例 3 腫瘍の電子顕微鏡写真 $(\times 6,000)$
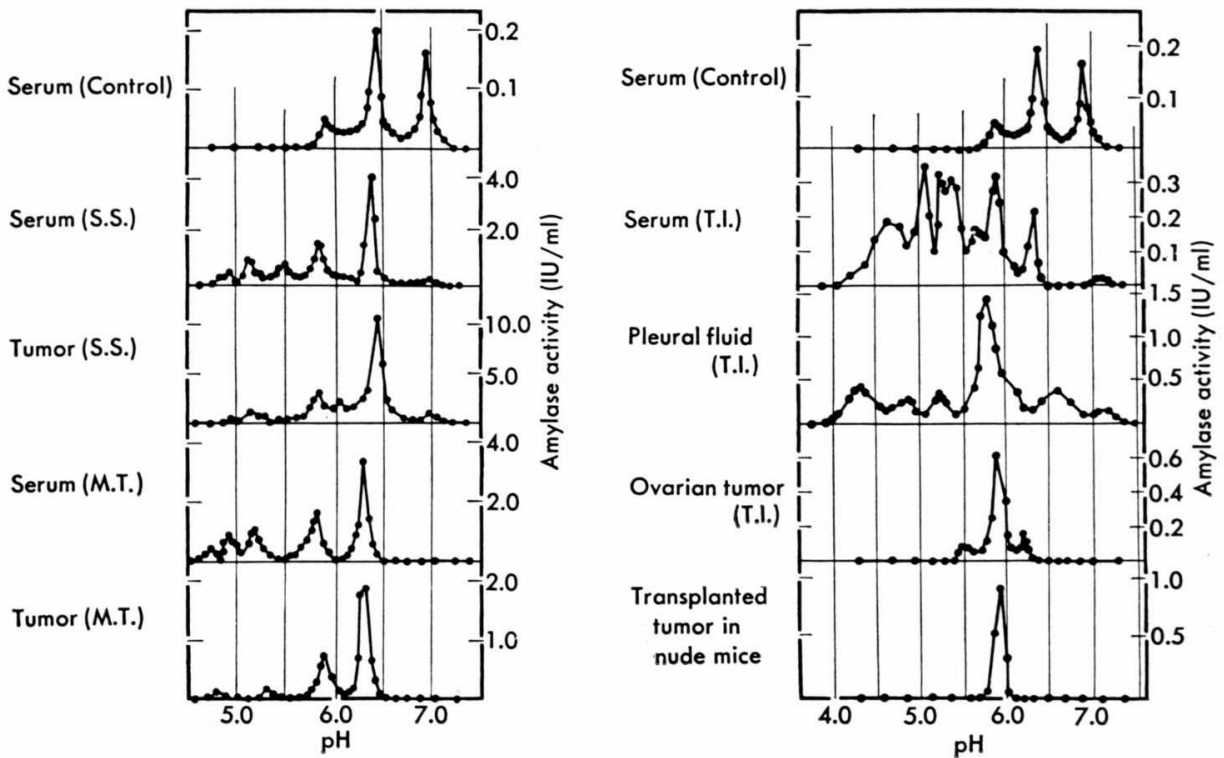

网 7. 等電点分画法による症例 $1,2,3$ 血清拉よび腫瘍中アミラーゼアイソザイムパターン

一ゼの主成分（pI=5.9） と一致する成分のみを示した (図 7 )。これまで，アミラーゼ産生腫瘍のアイソザイム 型は唾液腺型であると報告されている13). われわれの症 例 1,2 は確かにそのとおりであるが，症例 3 ではより低
い等電点を有するアイソザイムが主成分であった。その 等電点が正常血清中に存在する第 3 の成分, それは他の 2 つの成分である唾液腺型と膵臓型に比べると少ないが, その等電点 $\mathrm{p} I=5.9$ と一致するのは興味深い. 3 症例と 
も主成分の他にいくつかの小成分を伴っているが，新し いアイソザイムが発現したと考えるより，主成分の修飾 または分解によって生じた副産物と考学るのが妥当であ ろ5 ${ }^{16)}$.

症例 1,2 のアミラーゼの沈降係数はショ糖密度勾配超 遠心法で正常アミラーゼと同じ $4 \mathrm{~S}$ であった. 腫瘍産生 アルカリフォスファターゼやアミラーゼが巨大分子を呈 するといら報告があるが，2つの症例のアミラーゼは正 常の大きさである17,18).

さて腫瘍がなぜアミラーゼを産生するかといら問題は 非常に難しく，まだ何の手がかりもつかめていないのが 現状である。これはアミラーゼに限ったことではなく， その他の異所性酵素や異所性ホルモンについても同様に 産生機構は仮説の域を出ていない19)，そこで，アミラー ゼ産生機構についても, あえて無理に仮説を立てると次 のようなことが考えられる. 症例 1,2 はラジオイムノア ッセイでペプチドホルモンの存在が確かめられている. すなわち症例 1 では ACTH, $\beta \mathrm{MSH}, \mathrm{PTH}$ を産生し, 症例 2 では ACTH, $\beta \mathrm{MSH}$, calcitonin を産生している. このように肺癌がペプチドホルモンを産生することは稀 ではなく,時としてACTH分泌により正常副腎が制激さ れステロイドホルモンを分泌し, その結果としてクッシ ング症候群といらステロイドホルモン過剰の症状を呈す ることがある.ところで,ラット胎児の肺では出生前にア ミラーゼ活性が一過性に上昇する20) (図 8). この時期で は膵藏アミラーゼも一過性に上昇し，この上昇は血中グ ルココルチコイドの上昇の結果と考えられている20). 乙 たがって人とラットの種の違いを考慮せずにいえば, 腫 瘍から産生される ACTHにより刺激された副腎からグ ルココルチコイドが分泌される.それが腫瘍化によって 胎児肺の性状を帯びた肺癌細胞のアミラーゼ産生能を刺

Lng Parotid gl. Pancreas

\begin{tabular}{|c|c|c|c|}
\hline \multirow{2}{*}{\multicolumn{2}{|c|}{ Gestational day }} & \multicolumn{2}{|c|}{ (IU/g tissue) } \\
\hline & & & \\
\hline 15 & nd & nd & nd \\
\hline 17 & 1.2 & nd & 210 \\
\hline 21 & $\overline{15.2}$ & nd & 5,000 \\
\hline \multicolumn{4}{|c|}{ Postnatal day } \\
\hline 1 & 0.5 & nd & 1,300 \\
\hline 10 & 0.6 & 21 & 200 \\
\hline Adult & 0.8 & 9,000 & 5,200 \\
\hline
\end{tabular}

図 8. ラット肺, 耳下腺および膵臓のアミラーゼ活性
激すると考えたらどらであろらか. あるいは単に肺の胎 児期の性状であるアミラーゼ産生能が, 肝癌における $\alpha$ fetoprotein, 大腸癌に批ける carcinoembryonic antigen のように腫瘍化に伴う幼若化現象として出現したと考兄 たらどうであろらか.しかし，これらの考え方はいろい ろな点で無理がある. 例えば症例 1,2 とも血中グルココ ルチコイド值は正常値の上限であり，その上昇によるア ミラーゼ誘導は説明しにくい，仮に血中グルココルチコ イドが正常レベルでも腫瘍化によって癌細胞中にグルコ コルチコイドレセプターが出現し，そのためにアミラー ゼが誘導されたとしても，この説明は肺の正常組織や腫 瘍組織のレセプターを測定した上での議論ではないので 空想の域を出ない、またラット胎児肺に存在するアミラ 一ゼは膵蔵型であり, この時期では膵臓のアミラーゼ活 性値がきわめて高いので，消化管に分泌されたアミラー ゼが肺に逆流したとも考学られ，胎児肺がアミラーゼを 産生するといら根拠はまだ確定していない。いずれにせ よ, 腫瘍のアミラーゼ産生機構に関しては全く解明の手 がかりはつかめていず, 腫瘍産生アミラーゼの生化学的 性状を明らかにすることだけで精一杯というのが現状で ある。

\section{References}

1) W.D. Odell and A.Wolfsen: Cancer 3, ed. by F.F. Becker, Plenum Press, New York and London, pp. 81-120(1975).

2) W.H.FISHMAN and R.M.SINGER: ibid., pp. 57-80 (1975).

3) G.GewiRTZ and R.S. YAlow: J. Clin. Invest., 53, $1022(1974)$.

4) Y.Hirata, S.Matsukura, H.ImURA, M. NAKAMURA and A. TANAKA: J. Clin. Endocrinol. Metab., 42, 33(1976).

5) O.L.Silva, K. L. BECKeR, A. Primack, J. DOPPMAN and R.H. SNIDER: N.Eng. J. Med., 290, 1122(1974).

6) R.C.BENSON, B.L.RIGgS, B.M.PICKARD and C.D.ARnAUD: J.Clin. Invest., 54, 175(1974).

7) L.M. McManus, M.A. Naughton and A. MARTINEZ-HERnANDEZ: Cancer Res., 36, 3476 (1976).

8) L. Fishman, H.Mryayama, S.G. DRiscoll and W.H.FISHMAN: Cancer Res., 36, 2268(1976).

9) R.W. AMmAN, J.E.BerK, L. FRIDHANDLER, H. UEDA and W. WEGMANN: Ann.Int.Med.,78, 521 (1973).

10) T.TAKEUCHI, T.KAMEYA and T.Sugimura: "Pathophysiology of Carcinogenesis in Digestive 
Organs," eds. by E.Farber et al., Univ. of Tokyo Press, Tokyo/Univ. Park Press, Baltimore, pp. 351-362 (1977).

11) T. TAKeUCHI, Y. NaKagawa, M. OgaWA, T.KAWACHI and T.Sugimura: Clin. Chim. Acta, 77, 203(1977).

12) K. YASUDA and A.H. Coons: J. Histochem. Cytochem., 14, 303(1966).

13) K. Gomi, T.Kameya, M. Tsumuraya, Y. Shimosato, F.ZeZe, K. ABe and T. Yoneyama: Cancer, 38, 1645(1976).

14) T.Takeuchi, T.Matsushima, T.Sugimura, T. KozU, T. TAKEUCHI and T. TAKEMOTO: Clin. Chim. Acta, 54, 137 (1974).

15) T.TAKEUCHI, T.MATSUSHIMA and T.SUgimura: Clin. Chim. Acta, 60, 207(1975).

16) T. TAKeUChi, T.MATsushima, T.Sugimura, T. KOZU, T. TAKEUCHI and T. TAKEMOTO: Clin. Chim. Acta, 60, 205(1975).

17) K. ShinkAi and H.A.AKedo: Cancer Res., 32, 2307 (1972).

18) C. J.M. Lips, J. VAN dev Sluys Veer, J. A. VAN DEV DONK, R.H.VAN DAM and W.H.L. HACHENG: Lancet, i, 16(1978).

19) W. D. Ball: Dev. Biol., 41, 267 (1974).

20) T.TAKeuchi, M. OgaWa, C.Furihata, T. KAWACHI and T.SUGIMURA: Biochim. Biophys. Acta, 497, 657(1977).

\section{【質問】}

神大 2 内 大柣

(1) 肺炎でも hyperamylasemia をきたす場合があり 肺癌の hyperamylasemiaが ectopic production によ るのか，あるいは本来，肺に amylase があるのではな いか. 肺と hyperamylasemia に関して，どのように考 えて扣られるのか。

(2) human fetus の lung amylase を検索されたこ とがあるか。

\section{【答】}

(1) 肺にアミラーゼが存在するということは，Ballが
1974年ラット胎児肺で報告し20)，またわれわれも同様の 結果を得ている。しかし，肺がアミラーゼを産生すると いうことは証明されていないわわれわれは正常肺でアミ ラーゼの存在を螢光抗体法を用いて検索したが，気管支 粘膜上の分泌物が染まり，細胞中には陽性所見を見出せ なかった．われわれはアミラーゼがムチン様物質に親和 性を示し，しかも結合しても活性を有することを経験し ている．したがって，正常肺粘膜上の分泌物がアミラー ゼを結合していることは十分考えうるし，上記の実験結 果もその事実を意味すると思われる。このような事実か ら，肺炎のような分泌物の多く貯留する病態では分泌物 に結合していたアミラーゼがなんらかの機構で生体内に 逆流し，hyperamylasemia を呈することがありらると 考える. 肺癌の場合には, アミラーゼの局在が癌細胞中 に証明されるので，癌細胞がアミラーゼを産生している ものと考える.

（2） 20 週前後の胎児の肺については検索した．結果は， アミラーゼ活性は存在しなかった。ラット胎児肺でアミ ラーゼが証明されるのは出生前日くらいの時期であるの で，人胎児の場合も40週に近いものを検索すべきであろ 5 .

【質問】虎の門病院 中!!

1. 肺癌組織での高アミラーゼの確率は血清より高く ないか.

2. 正常肺組織内のアミラーゼ局在はどこか. 【答】

(1) 正常肺のアミラーゼ值の上限をどこにとるかで決 まってくると思う。例えば，正常值を $1,000 \mathrm{mI} . \mathrm{U} . / \mathrm{g}$ tissue 以下にすると確率はほぼ一致する.

(2) 正常肺組織内には，現在までのところアミラーゼ の局在は観察していない，細胞外の分泌物中にはアミラ 一ゼが存在し, この事実は大柣先生への回答で詳しく述 ベたところである. 